Article

\title{
Biological Characteristics of Experimental Genotype Mixtures of Cydia Pomonella Granulovirus (CpGV): Ability to Control Susceptible and Resistant Pest Populations
}

\author{
Benoit Graillot ${ }^{1,2}$, Sandrine Bayle ${ }^{1}$, Christine Blachere-Lopez ${ }^{1,3}$, Samantha Besse ${ }^{2}$, \\ Myriam Siegwart ${ }^{4}$ and Miguel Lopez-Ferber ${ }^{1, *}$ \\ 1 LGEI, Ecole des Mines d'Alès, Institut Mines-Telecom et Université de Montpellier Sud de France, \\ 6 Avenue de Clavières, 30319 Alès, France; graillot.benoit@gmail.com (B.G.); \\ sandrine.bayle@mines-ales.fr (S.B.); christine.blachere-lopez@mines-ales.fr (C.B.-L.) \\ 2 Natural Plant Protection, Arysta LifeScience Group, Avenue Léon Blum, 64000 Pau, France; \\ samantha.besse@arysta.com \\ 3 INRA, 6, Avenue de Clavières, 30319 Alès, France \\ 4 INRA, unité PSH, Agroparc, 84914 AVIGNON Cedex 9, France; myriam.siegwart@avignon.inra.fr \\ * Correspondence: miguel.lopez-ferber@mines-ales.fr; Tel.: +33-466-78-27-04 \\ Academic Editor: Eric O. Freed \\ Received: 12 November 2015; Accepted: 11 May 2016; Published: 21 May 2016
}

\begin{abstract}
The detection of resistance in codling moth (Cydia pomonella) populations against the Mexican isolate of its granulovirus (CpGV-M), raised questions on the sustainability of the use of this biological insecticide. In resistant host cells, CpGV-M is not able to complete its replication cycle because replication is blocked at an early step. Virus isolates able to overcome this resistance have been characterized-among them, the CpGV-R5 isolate. In mixed infections on resistant insects, both CpGV-M and CpGV-R5 viruses replicate, while CpGV-M alone does not induce mortality. Genetically heterogeneous virus populations, containing 50\% of each CpGV-M and CpGV-R5 appear to control resistant host populations as well as CpGV-R5 alone at the same final concentration, even if the concentration of CPGV-R5 is only half in the former. The use of mixed genotype virus preparations instead of genotypically homogeneous populations may constitute a better approach than traditional methods for the development of baculovirus-based biological insecticides.
\end{abstract}

Keywords: CpGV; Lepidoptera; genetic heterogeneity; resistance; biological control

\section{Introduction}

The Cydia pomonella granulovirus Mexican isolate (CpGV-M) (species Cydia pomonella granulovirus; genus Betabaculovirus; family Baculoviridae) [1] was discovered by Tanada in 1964 [2]. This virus has a narrow host range, limited to the codling moth (Cydia pomonella) and some related moth species. The CpGV-M genome comprises double stranded circular DNA of $123.5 \mathrm{~kb}$ in length [3]. CpGV has been registered as a biocontrol agent in different countries to control the codling moth in apple and pear orchards. In Europe, most commercial formulations of CpGV are derived from the original CpGV-M isolate [4], which has been distributed to many different laboratories and companies, and amplified on laboratory colonies of codling moth. This isolate appears to have limited genetic diversity [5].

Resistance to CpGV-M was first reported in Germany in 2005 [6], and subsequently in France [7]. Recent reports indicate a wide distribution of CpGV-resistant populations across Europe [8] but not in other continents. The resistance observed in all Europe appears to have a similar genetic origin. The resistance determinant (gene) is located in the sex chromosome of the host and is dominant. Resistant 
females are $Z^{R} W$, while resistant males can be $Z^{R} Z^{R}$ or $Z^{R} Z^{S}$ [9]. The mechanism of resistance, analyzed on the laboratory colony CpRR1, appears to involve early blocking of viral replication in host cells [10].

Research was conducted to obtain new viral variants able to overcome the resistance mechanisms of host cells. Extensive collections of CpGV isolates were carried out in the original apple distribution area [11]. New isolates able to control resistant populations were obtained by selecting isolates from laboratory and field collections that were capable of lethal infection of resistant codling moth larvae [12,13], proving that an important degree of genetic variability is present in CpGV populations and that this variability is reflected in biological (phenotypic) differences. The inability of CpGV-M to successfully replicate in resistant hosts is linked to a modification of the pe38 gene, the function of which remains unclear [14].

Both resistant and susceptible individuals are usually present simultaneously in field host populations and this raises questions on the ability of a single viral genotype to provide adequate control of the pest population, and the risk of the development of resistance to other genotypes in the virus population.

Genetic diversity in parasite populations is an important driver for the evolution of host defense capabilities $[15,16]$. Natural virus populations are genetically heterogeneous and certain genotypic variants may be more prevalent than others $[17,18]$. The fact that minority genotypes are not eliminated in wild populations suggests that this heterogeneity is important for virus survival [19].

As pathogens and their hosts are continuously coevolving, it was thought that pest populations were unlikely to develop resistance to a pathogen-based product [20], contrary to the resistance observed with chemical insecticides [21]. The development of insect pathogens for use in inundative biological control has relied on this assumption for planning the timing and frequency of application of virus Occlusion Bodies (OBs). However, Briese et al. [22] noted that if selection for resistance was possible in the laboratory, the same could occur in natural pest populations subjected to continuous exposure to the virus.

A major question arising is why resistance to CpGV spread recently in apple and pear agrosystems and has not been detected in natural populations of codling moth. Fuxa pointed out the importance of the ability of the virus to adapt and therefore overcome resistance of the host in natural conditions [23]. Possible answers might involve differences between the genetic homogeneity of virus-based insecticides over space and time and the diversity of natural isolates. The genotypic diversity present in the virus population at a given moment comprises variation in geographical diversity and temporal diversity with changes in the relative frequency or identity of virus genotypes over time.

Genetic variability has been described both in nucleopolyhedroviruses (NPVs, family Baculoviridae, genus Alphabaculovirus) [24-26] and in granuloviruses (GV) populations $[5,27,28]$. In recent years, a renewal of interest in the role of genetic diversity has led to studies on the genetic structure of NPV wild populations [25] and the mechanisms involved in generating and maintaining such diversity. The phenomenon of co-infection of host cells has been studied and shown to be a generalized trait in Autographa californica multicapsid nucleopolyhedrovirus (AcMNPV) [29]. Co-occlusion, i.e., the possibility of transmission of more than one genotype in a single $\mathrm{OB}$, has been demonstrated for Spodoptera frugiperda multiple nucleopolyhedrovirus (SfMNPV) [30,31]. Genetic variability in NPVs seems to be higher than in GVs. This was partially attributed to differences in the physical structure of OBs. In NPVs, a single OB contains multiple virions, which can represent the whole population diversity. In contrast, in GVs, a single OB contains a single virion. Consequently, infection following ingestion of one $\mathrm{OB}$ might result in a genotypically diverse infection in the former, and to a clonal infection in the later.

In the virus-host system SfMNPV and Spodoptera frugiperda, Simon et al. have shown that genetic heterogeneity contributes to the efficacy of the viral population by increasing the transmissibility of virus OBs [32], and that genetically diverse experimental populations are more effective insecticides 
than any of the individual component genotypes alone. In this manuscript, we have tested this approach with CpGV in susceptible and resistant populations of the codling moth.

\section{Materials and Methods}

\subsection{Insects}

Two laboratory colonies were used in this study: the susceptible colony CpNPP, used for the industrial production of CpGV by Natural Plant Protection SA (Pau, France), is susceptible to both CpGV-M and CpGV-R5 virus isolates. CpNPP has been reared in the laboratory for more than 25 years and originally comes from northern France.

The resistant colony $\mathrm{R}_{\mathrm{GV}}$ of Cydia pomonella was derived from a natural resistant population (St-A) found in the region of Saint-Andiol (Bouches-du-Rhône, France) as previously described [13]. The $\mathrm{R}_{\mathrm{GV}}$ colony harbors the major genetic determinant for resistance that is present in resistant European populations [13]. As this gene is located on the $\mathrm{Z}$ sex chromosome of the insect, and the induced phenotype is dominant [9], and using our approach of mass selection, it is impossible to completely eliminate the susceptible allele, as heterozygous males $\left(Z^{R} Z^{S}\right)$ are resistant to $\mathrm{CpGV-M}$ infection. Accordingly, the $\mathrm{R}_{\mathrm{GV}}$ colony is periodically subjected to artificial selection by rearing the survivors of a CpGV-M treatment in order to maintain a high level of resistance [13].

Both colonies are mass reared on artificial diets as previously described [13].

\subsection{Viruses}

The virus isolates used in this work, CpGV-M (laboratory stock 2020-s1) and CpGV-R5 (laboratory stock 2016-r16) have been described previously [33]. CpGV-R5 is able to overcome the resistance of the $\mathrm{R}_{\mathrm{GV}}$ colony and produces a productive lethal infection in resistant insects. No genetic polymorphism has been detected in this virus isolate [33].

\subsection{Mixed Viral Populations}

Five mixed virus populations were constructed by mixing OBs resulting from infections of pure isolates CpGV-M and CpGV-R5 propagated on permissive CpNPP larvae. The proportions of each isolate in the mixed virus populations were $99 \%$ CpGV-M + 1\% CpGV-R5; 95\% CpGV-M + 5\% CpGV-R5; 90\% CpGV-M + 10\% CpGV-R5; 50\% CpGV-M + 50\% CpGV-R5; 10\% CpGV-M + 90\% CpGV-R5. Pure CpGV-M and CpGV-R5 were used as control populations. These OBs are referred as passage zero OBs (P0).

\subsection{Amplification of the Different Viral Mixed Populations}

Amplification of the different P0 populations was performed as previously described $[33,34]$. Briefly, third-instar (L3) susceptible or resistant larvae were inoculated using $50 \mu \mathrm{L}$ of a mixed genotype suspension at a concentration of $800 \mathrm{OBs} / \mu \mathrm{L}$, which was deposited on the surface of a formaldehyde-free diet (Stonefly Heliothis Diet, Ward's Science, Rochester, NY, USA) in 24-well plates. One L3 larva was then placed in each well, the plates sealed and incubated at $25^{\circ} \mathrm{C}\left( \pm 1^{\circ} \mathrm{C}\right)$ with a $16: 8 \mathrm{~h}$ (light/dark) photoperiod and a relative humidity of $60 \%( \pm 10 \%)$. After 4 days, larvae showing clear signs of infection were removed from the wells and kept without diet at $25^{\circ} \mathrm{C}$ for one more day. Infected larvae were then crushed in distilled water and the resulting mixture was filtered through nylon to eliminate debris. The suspension was then centrifuged $5 \mathrm{~min}$ at $8000 \times g$, and the resulting pellet was resuspended in distilled water. The final volume of the virus stocks was of $100 \mu \mathrm{L}$ per infected larva, which corresponds to $10^{11} \mathrm{OB} / \mathrm{mL}$ on average. This suspension constituted the first amplification (P1) of each viral mixture. 


\subsection{Bioassays}

Bioassays were performed on virus populations, (P0), using established protocols [13]. Briefly, 96-well plates containing $200 \mu \mathrm{L}$ of formaldehyde-free diet (Stonefly Heliothis Diet, Ward's Science, Rochester, NY, USA) were inoculated by spreading $6 \mu \mathrm{L}$ of an OB suspension over the surface of each piece of diet by pipetting. Diet in control wells was treated with the same volume of distilled water. One larva, aged less than $12 \mathrm{~h}$, was placed in each well. Six CpGV concentrations from 2 to $6250 \mathrm{OBs} / \mu \mathrm{L}$ on fivefold serial dilutions were used in all but CpGV-M bioassays on resistant populations, in which concentrations between 10 and 3,000,000 OBs / $\mu \mathrm{L}$ were employed. Early mortality due to handling was excluded from the test. Virus induced mortality was recorded at 7 days post-infection. Mortality data were subjected to probit analysis [35] using the POLO + software [36]. To test the hypothesis of Independent Joint Action, the $\chi^{2}$ statistic was used following Polo Mix Software (LeOra Software) [36]. Each bioassay was repeated at least three times. Tests presenting a high mortality in controls $(>10 \%)$ were rejected. The results for each treatment were pooled after verification of homogeneity.

\subsection{Evaluation of the Relative Proportions of Each Genotype by PCR}

\subsubsection{DNA Extraction}

OB stocks were obtained as detailed in 2.4. Lysis of OBs was performed in order to extract viral DNA from the OB suspensions obtained previously (P0-P1). A volume of $100 \mu \mathrm{L}$ of extraction buffer $\left(0.2 \mathrm{M} \mathrm{Na}_{2} \mathrm{CO}_{3}, 0.34 \mathrm{M} \mathrm{NaCl}, 0.02 \mathrm{M}\right.$ EDTA; $\left.\mathrm{pH}=10.5\right)$ was added to $100 \mu \mathrm{L}$ of OB suspension $\left(\sim 1 \times 10^{7} \mathrm{OBs} / \mu \mathrm{L}\right)$ and incubated $30 \mathrm{~min}$ at $37^{\circ} \mathrm{C}$. The suspension was neutralized with $20 \mu \mathrm{L} 1 \mathrm{M}$ $\mathrm{HCl}$ and $11 \mu \mathrm{L} \mathrm{10 \%} \mathrm{(wt/vol)} \mathrm{sodium} \mathrm{dodecyl} \mathrm{sulfate} \mathrm{(SDS)} \mathrm{was} \mathrm{added.} \mathrm{A} 1$ min centrifugation step at $13,000 \mathrm{rpm}$ was performed and the resulting supernatant was diluted $(1 / 100)$ in sterile distilled water before (polymerase chain reaction) PCR amplification.

\subsubsection{PCR}

\section{Identification of the Virus Genotype}

Restriction endonuclease analyses indicated that both CpGV-M and CpGV-R5 were likely to be genotypically homogeneous [33]. CpGV-R5 has been completely sequenced (unpublished work). By comparing the published genome sequence of CpGV-M and CpGV-R5, regions presenting differences were mapped. Gebhardt and coworkers [14] demonstrated that the ability of CpGV isolates to replicate in CpRR1 resistant hosts is due to a modification of the viral pe38 gene. Similarly to their results, the difference between CpGV-M and CPGV-R5 pe38 genes resides in a 24 bp. Gebhart et al. [14] suggested that the difference corresponds to an insertion in CpGV-M. This difference occurs in a repeated region of the gene, which impedes to differentiate between the two genotypes by qPCR. Accordingly, a pair of classical PCR primers was designed CpGV 19003R (5' ccggctgcagCGAGTCGAGCACCACCATTA 3') and CpGV18705F ( $5^{\prime}$ cgcgggatccACGGTGTGTCATTAGCCACC $3^{\prime}$ ), the numbers refer to the nucleotide positions in NC_002816 CpGV-M sequence. CPGV ORF 24 runs counterclockwise. These primers amplify fragments of differing size in the two genotypes (295 pb for CpGV-M and $315 \mathrm{bp}$ for CpGV-R5), making it possible to discriminate between them. A restriction site was added at the extremity of each primer; PstI and BamHI for CpGV-18705F and CpGV-19003R, respectively, to facilitate eventual cloning.

PCR was performed in a final volume of $50 \mu \mathrm{L}$, containing $2 \mu \mathrm{L}$ of each primer $(10 \mathrm{pmol} / \mu \mathrm{L}$ MWG-Eurofins), $2 \mu \mathrm{L}$ of viral DNA (ca. $10 \mathrm{pg}$ ), $20 \mu \mathrm{L}$ of $2.5 \mathrm{X}$ PCR Hotmastermix (5 PRIME $\mathrm{GmbH}$, Hilden, Germany) and $24 \mu \mathrm{L}$ water. The amplification conditions were as follows: a $3 \mathrm{~min}$ predenaturation at $94{ }^{\circ} \mathrm{C}$, followed by 35 cycles of $15 \mathrm{~s}, 94{ }^{\circ} \mathrm{C} ; 40 \mathrm{~s}, 65^{\circ} \mathrm{C}$ and $1 \mathrm{~min} 30 \mathrm{~s}, 72{ }^{\circ} \mathrm{C}$.

The amplified fragments were separated in a $3 \%$ agarose gel (NOVAGEL GQT, Conda S.A., Torrejon de Ardoz, Madrid, Spain) in tris-borate-ethylenediaminetetraacetic acid (TBE) buffer. Fragments were visualized on a UV transiluminator after ethidium bromide staining. (Figure 1). 


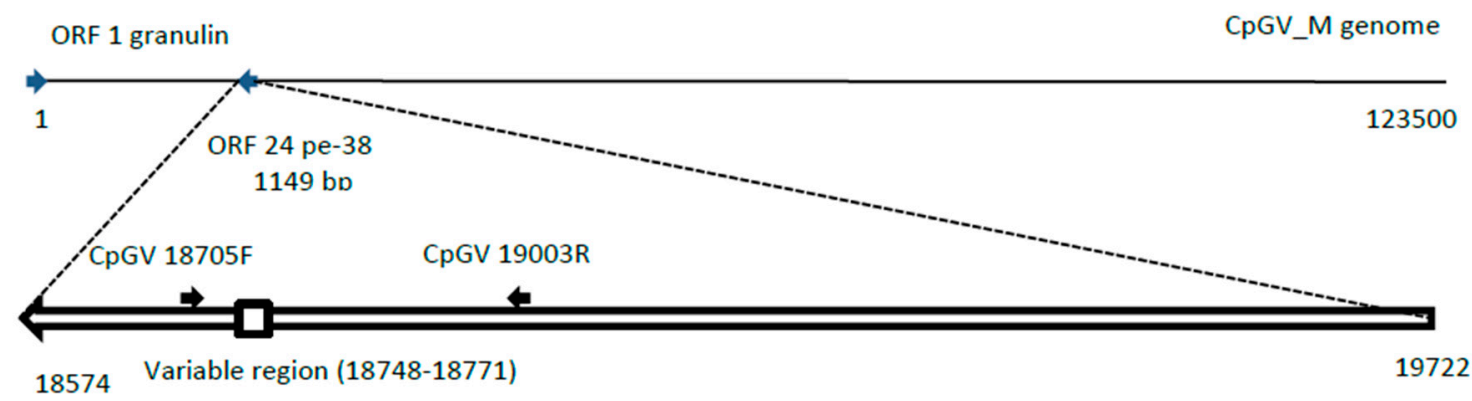

Figure 1. Schematic location of the PCR primers for amplification of the variable region as described in Reference [14]. Numbers refer to Cydia pomonella granulovirus Mexican isolate (CpGV-M) genome NC_002816 [3].

\section{Results}

\subsection{Efficacy of Viral Isolates}

The concentration-mortality response of each viral population was estimated by probit analysis in our previous works [33,34] (Table 1).

CpGV-M was highly pathogenic towards the susceptible insect colony, CpNPP (Table 1, line 1), while even with high virus concentrations, the mortality on the $\mathrm{R}_{\mathrm{GV}}$ resistant colony was very low. The $\mathrm{LC}_{50}$ value of CpGV-M OBs in $\mathrm{R}_{\mathrm{GV}}$ larvae was $2.22 \times 10^{6} \mathrm{OBs} / \mu \mathrm{L}$, (Table 1 , line 5 ). It has not been possible to calculate a $\mathrm{LC}_{90}$ value as $\mathrm{R}_{\mathrm{GV}}$ population is not susceptible to this isolate. No mortality was observed when resistant $R_{\mathrm{GV}}$ larvae were inoculated with CpGV-M OBs at the standard concentration used for the amplification of the virus populations $(800 \mathrm{OB} / \mu \mathrm{L})$, as observed previously.

In contrast, $\mathrm{CpGV-R5}$ was highly pathogenic to both insect colonies. The $\mathrm{LC}_{50}$ of $\mathrm{CpGV}$-R5 alone ranged between $6.76 \mathrm{OBs} / \mu \mathrm{L}$ for the CpNPP colony (Table 1, line 4) and $22.43 \mathrm{OBs} / \mu \mathrm{L}$ for the $\mathrm{R}_{\mathrm{GV}}$ colony (Table 1, line 8). For susceptible colonies, CpGV-R5 was as pathogenic as CpGV-M (compare Table 1, lines 1 and 4) [33,34].

For $\mathrm{CPNPP}$ susceptible insects, the $\mathrm{LC}_{50}$ observed for all virus populations tested varied between 6.76 and $13.10 \mathrm{OB} / \mu \mathrm{L}$ (Table 1, lines 1 to 4 ). The dose/response relationships although quite close, are statistically different $\left(\chi^{2}=23.13\right.$, d.f. $\left.=6, p<0.01\right)$.

For the $\mathrm{R}_{\mathrm{GV}}$ insect colony, the presence of CpGV-R5 genotypes, even at a low proportion $(10 \%)$, results in a marked increase in pathogenicity compared to CpGV-M alone (measured both at the $\mathrm{LC}_{50}$ and $\mathrm{LC}_{90}$ levels) (Table 1, line 6).

For the mixed virus population, 50\% CpGV-M + 50\% CpGV-R5, the Independent Joint Action hypothesis was rejected both on susceptible and resistant insects, (Table 2), suggesting a positive interaction. However, when increasing the relative proportion of CPGV-M to $90 \%$ (M90\%-R10\% mix), the test did not reach the statistical signification threshold $(\alpha=0.05)$ (Table 2). 
Table 1. Pathogenicities, measured by Lethal Concentration ( $\mathrm{LC}_{50}$ and $\left.\mathrm{LC}_{90}\right)$ of two viral isolates of Cydia pomonella granulovirus, $\mathrm{CpGV-M}$ and $\mathrm{CpGV-R5}$ and mixtures of these viruses in different proportions in C. pomonella laboratory colonies that were susceptible (CpNPP) and resistant (R $\mathrm{GV})$ to $\mathrm{CpGV-M}$. Lines $1,4,6$ and 8 , are reference assays that have been published previously $[33,34]$. Bioassays were performed by diet surface contamination with neonate larvae. Mortality was scored at 7 days post-infection.

\begin{tabular}{|c|c|c|c|c|c|c|c|c|c|}
\hline & \multirow{2}{*}{ Insect Strain } & \multicolumn{2}{|c|}{ Composition of Virus Mixtures (\%) } & \multirow{2}{*}{ No. Controls } & \multirow{2}{*}{ No. Insects Tested } & \multicolumn{2}{|c|}{ Lethal Concentrations in OBs $/ \mu \mathrm{L}(95 \% \mathrm{CI})$} & \multirow{2}{*}{ Slope \pm SE } & \multirow{2}{*}{$x^{2}$} \\
\hline & & CpGV-M & CpGV-R5 & & & $\mathrm{LC}_{50}$ & $\mathrm{LC}_{90}$ & & \\
\hline 1 & CpNPP & 100 & 0 & 257 & 529 & $13.10(6.55-23.20)$ & $223.10(110.70-654.18)$ & $1.04 \pm 0.09$ & 5.99 \\
\hline 2 & & 90 & 10 & 256 & 541 & $12.40(4.92-25.42)$ & $119.03(52.17-616.73)$ & $1.31 \pm 0.12$ & 11.95 \\
\hline 3 & & 50 & 50 & 257 & 518 & $10.69(6.67-16.11)$ & $94.12(56.48-197.99)$ & $1.36 \pm 0.12$ & 4.26 \\
\hline 4 & & 0 & 100 & 257 & 533 & $6.76(2.59-13.37)$ & $59.63(27.54-278.55)$ & $1.36 \pm 0.13$ & 11.42 \\
\hline 5 & $\mathrm{R}_{\mathrm{GV}}$ & 100 & 0 & 476 & 1143 & $2.22 \times 10^{6}\left(1.19 \times 10^{6}-5.67 \times 10^{6}\right)$ & - & $0.50 \pm 0.07$ & 10.6 \\
\hline 6 & & 90 & 10 & 215 & 817 & $201.78(139.95-280.83)$ & $2.35 \times 10^{3}\left(1.51 \times 10^{3}-4.23 \times 10^{3}\right)$ & $1.20 \pm 0.09$ & 5.46 \\
\hline 7 & & 50 & 50 & 354 & 989 & $16.45(8.41-29.07)$ & $311.55(151.53-938.21)$ & $1.00 \pm 0.06$ & 16.35 \\
\hline 8 & & 0 & 100 & 176 & 369 & $22.43(13.73-34.36)$ & $410.67(240.16-846.43)$ & $1.02 \pm 0.11$ & 3.60 \\
\hline
\end{tabular}

Table 2. Results of the Independent Joint Action test for mixed virus populations M50-R50 and M90-R10 compared to genotypically homogeneous populations of Cydia pomonella granulovirus CpGV-M and CpGV-R5.

\begin{tabular}{|c|c|c|c|c|c|}
\hline \multirow{2}{*}{ Insect Strain } & \multicolumn{2}{|c|}{ Composition of Virus Mixtures (\%) } & \multirow{2}{*}{ Chi-Square } & \multirow{2}{*}{ Degrees of Freedom } & \multirow{2}{*}{$\mathbf{P}$} \\
\hline & CpGV-M & CpGV-R5 & & & \\
\hline \multirow{2}{*}{ CpNPP } & 50 & 50 & 91.002 & 6 & $<0.01$ \\
\hline & 90 & 10 & 8.98 & 6 & $>0.05$ \\
\hline \multirow[t]{2}{*}{$\mathrm{R}_{\mathrm{GV}}$} & 50 & 50 & 40.276 & 6 & $<0.01$ \\
\hline & 90 & 10 & 4.581 & 6 & $>0.05$ \\
\hline
\end{tabular}




\subsection{Specificity of the Genotype Markers}

The suitability of the primers was tested both on the pure virus isolates CpGV-M and CpGV-R5 and on the laboratory mixed virus populations (P0). Single amplification fragments of the expected length were obtained for CpGV-M and CpGV-R5 pure isolates, confirming the specificity of the primers. For mixed P0 virus populations, both fragments were detected. (Figure 2a). Fragments of higher size were always found in the mixed OB extractions. As they appear before these OB replicate in the host, they cannot reveal a rearrangement, and must represent an artifact. They have not been analyzed further. No amplification was observed on PCR using uninfected larvae from the two colonies (data not shown).

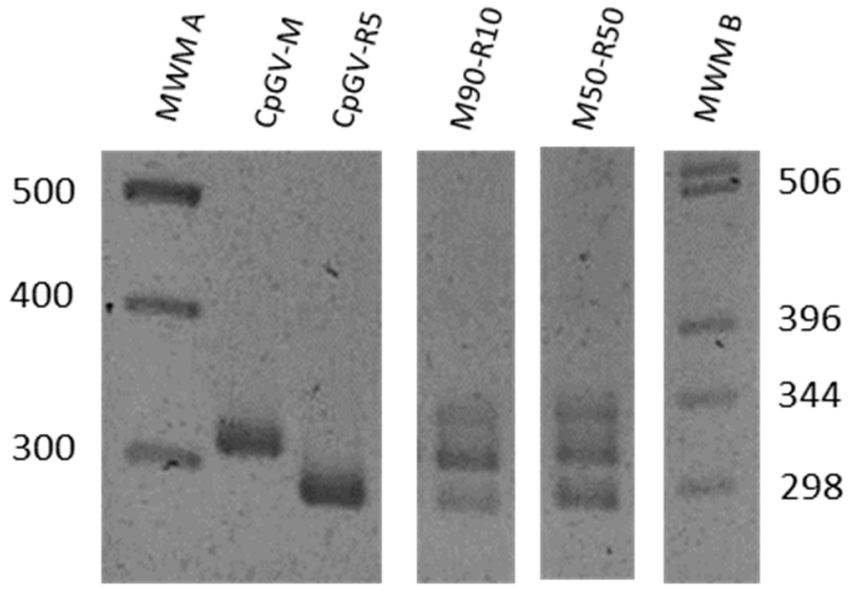

(a)

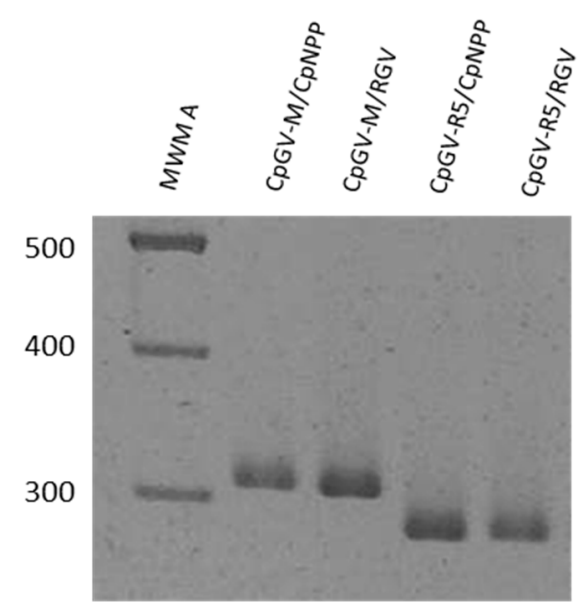

(b)

Figure 2. Gel electrophoresis of PCR products revealing the variability on the pe38 region of Cydia pomonella granulovirus populations obtained by mixing isolates CpGV-M and CpGV-R5 on the proportions indicated (a) PCR of Occlusion Bodies (OBs) of pure virus isolates, and of mixed OBs; (b) PCR of OBs obtained after inoculation in both host colonies at $800 \mathrm{OB} / \mu \mathrm{L}$ in all but CpGV-M on $\mathrm{R}_{\mathrm{GV}}$ that was inoculated at 30,000 OB/ $\mu \mathrm{L}$. MWM A: Molecular weight marker GeneRuler $100 \mathrm{bp}$ DNA Ladder (Fermentas, Burlington, ON, Canada). MWM B: 1 kb DNA Ladder (Invitrogen, Carlsbad, CA, USA).

\subsection{Replication of Viral Genotypes in Different Hosts}

OBs produced in both susceptible and resistant host colonies after infection with the experimental virus mixed populations were analyzed using this approach. Following infection of CpNPP and $\mathrm{R}_{\mathrm{GV}}$ hosts with CpGV-R5, no CpGV-M markers were detected in the progeny OBs (Figure 2b). Similarly, in OBs produced in CpNPP following infection with CpGV-M, no CpGV-R5 markers were detected. Inoculation of $\mathrm{R}_{\mathrm{GV}}$ larvae with $\mathrm{CpGV}-\mathrm{M}$ at a concentration of $800 \mathrm{OB} / \mu \mathrm{L}$ did not result in virus-induced mortality. To verify the absence of persistent infection of $R_{\mathrm{GV}}$ or contamination of our CpGV-M virus stock with CpGV-R5, $R_{G V}$ larvae were inoculated at a concentration of 30,000 OBs/ $\mu \mathrm{L}$. Even at this elevated concentration, no CpGV-R5 markers were detected in progeny OBs from the few (2 out of 24) larvae that subsequently developed obvious signs of infection.

Markers corresponding to both CpGV-M and CpGV-R5 were detected in the progeny OBs of each mixture produced in CPNPP insects, indicating that both viruses were able to infect host cells, replicate and produce OBs (Figure 3a). Surprisingly, markers corresponding to both virus isolates were also detected in the viral progeny of each mixed virus population amplified in $\mathrm{R}_{\mathrm{GV}}$ indicating that CpGV-M was able, in the presence of CpGV-R5, to infect resistant host cells and to replicate. (Figure 3b). Higher size fragments are observed. They are considered as artifacts, as on PCR of mixed P(0) OBs. 


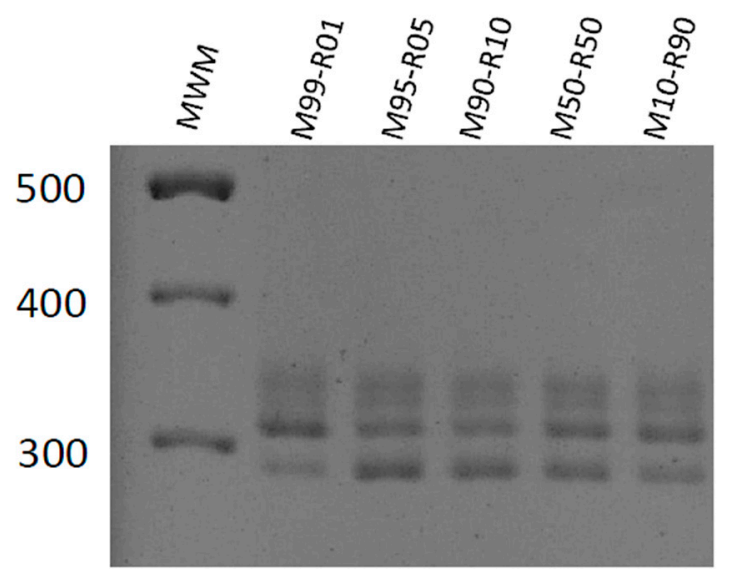

(a)

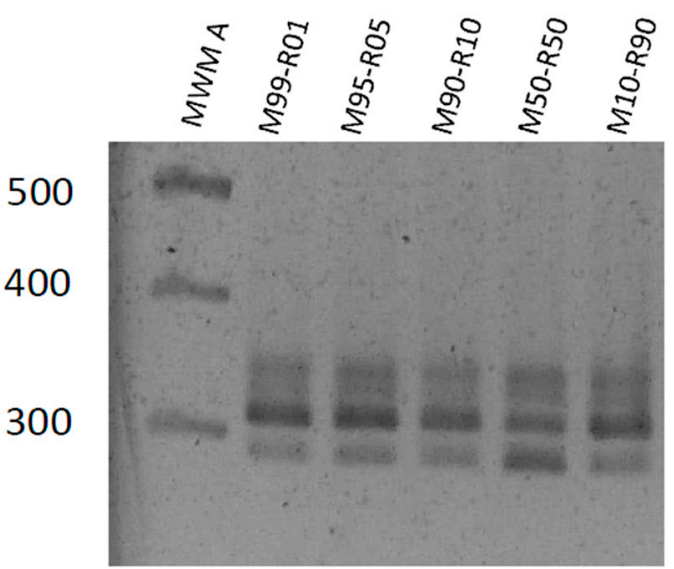

(b)

Figure 3. Gel electrophoresis of PCR products on P1 OBs obtained upon amplification of each virus mixed population. (a) on susceptible (CpNPP) larvae; $(\mathbf{b})$ on resistant $\left(\mathrm{R}_{\mathrm{GV}}\right)$ larvae. MWM A: Molecular weight marker GeneRuler 100 bp DNA Ladder (Fermentas, Burlington, ON, Canada).

\section{Discussion}

On the susceptible colony CpNPP, both CpGV-M and CpGV-R5 alone can infect and kill the insects.

On the resistant colony $\mathrm{R}_{\mathrm{GV}}$, the level of mortality obtained using pure CpGV-R5 was comparable to that of CpGV M on susceptible CpNPP colony (Table 1).

Using the $\mathrm{R}_{\mathrm{GV}}$ colony, a lethal infection has been obtained by inoculating resistant insects with very high concentrations of CpGV-M (Table 1). However, no progeny viruses were recovered following inoculation of CpRR1 resistant insects with CPGV-M per os and by injection [10]. The difference in our results compared to the previously published results can be attributed to the dose range used. Asser-Kaiser and coworkers [10] carried out their test with a maximum concentration of $2 \times 10^{5} \mathrm{OB} / \mathrm{mL}$ of diet, while we have checked up to $2 \times 10^{8} \mathrm{OB} / \mathrm{mL}$ of diet. Only when reaching concentrations higher than $10^{6} \mathrm{OB} / \mathrm{mL}$ did we start to observe the characteristic symptoms of infection by baculovirus in $\mathrm{R}_{\mathrm{GV}}$ larvae. At concentrations of $800 \mathrm{OB} / \mu \mathrm{L}$ (that is, $2.4 \times 10^{4} \mathrm{OB} / \mathrm{mL}$ of diet), $\mathrm{CpGV}$ does not induce mortality in resistant $\mathrm{R}_{\mathrm{GV}}$ larvae. Although only $\mathrm{R}_{\mathrm{GV}}$ larvae showing clear symptoms of infection were used for PCR, the amplification obtained using high virus concentration could be due to the inoculum OB that contaminated the larvae. Even in these conditions, no CpGV-R5 specific band was observed, as it would be expected if a latent infection was ongoing.

As CpGV-M does not induce mortality in resistant insects at the concentration of $800 \mathrm{OB} / \mu \mathrm{L}$, using artificial mixed genotype preparations, we would expect a positive correlation between the relative proportion of CpGV-M in the inoculum and the dose required to kill larvae. This was clearly not the case. The presence of CPGV-M in the inoculum contributed to the overall pathogenicity of the mixed virus population. The markers we selected are linked to the ability to replicate in resistant hosts, recently demonstrated to reside in the pe38 viral gene [14]. This means that a virus containing the " $\mathrm{M}$ " version of $p 38$ should not be able to productively infect a resistant insect. Given this scenario, we expected that no " $\mathrm{M}$ " type pe38 would be present in the progeny OBs that replicated in $\mathrm{R}_{\mathrm{GV}}$ insects. The presence of markers originating from both genotypes in the progeny of all mixed virus populations indicates that both viruses infected the larvae and replicated productively. The mechanism involved in the blocking of CpGV-M replication in resistant insects can be overcome, at least partially, by the presence of CpGV-R5.

Helper mechanisms can be classified in two main classes, those acting in trans and those acting in cis. Tanada and coworkers [37] first described baculovirus synergistic factors by analyzing the helper action of a granulovirus on a nucleopolyhedrovirus. They demonstrated that this effect occurred in trans; that is, one particle (an OB of a granulovirus) could help another particle (a virion of a 
nucleopolyhedrovirus) to initiate the infection of insect midgut cells. This action is due to the presence of a perithrophic membrane (PM) degradating enzyme present in the granulovirus OBs [38]. A different blocking on the infection of midgut cells has been observed when one or more of the components of the virion are absent. These components are called Per Os Infectivity proteins (PIFs) [39]. For these proteins, helper action must be in cis. The helper protein needs to be in the same particle [40].

A detailed analysis of the blocking point for CPGV-M infection of the CpRR1 colony of resistant insects has been published [10]. These authors demonstrated that the mechanism involved in resistance was not linked to midgut peritrophic membrane degradation. Moreover, in resistant CpRR1 insects challenged with the recombinant virus bacCpGVhsp-eGFP, based on CpGV-M, these authors detected a few cells in which expression of a marker carried by the virus was ongoing (see Figure $4 \mathrm{~d}$ in Reference [10]), but generalized infection never occurred. Consequently, a model of generalized host cell/virus incompatibility has been proposed [10]. The results of our study reveal that the helper action of CpGV-R5 occurs when mixing OBs that had been produced independently in different hosts. This suggests the presence of a trans-acting effect that acts both at the level of the midgut and other larval tissues in resistant insects.

A major difference between multicapsid nucleopolyhedroviruses (MNPVs) and GVs should be considered. In MNPVs, OBs contain Multiple Occlusion Derived Virions (ODV), and each ODV contain a variable number of genomes. Defective virus genomes can be cooccluded in the same OB and probably co-enveloped in the same virion with replication-autonomous genomes, and can thus be transmitted together to a new host, the complete genome acting as a helper [41]. In GVs, OBs carry a single virion containing a single genome. The presence of both CpGV-M and CpGV-R5 genomes in a given larva relies on the ingestion of independent OBs.

The $\mathrm{LD}_{50}$ for CpGV-M in susceptible insects has been estimated at 1.2-5.0 OBs/larva [4]. In our tests, $50 \%$ mortality for CpGV-M in such susceptible insects is obtained with a concentration of $13.10 \mathrm{OB} / \mu \mathrm{L}$. Consequently, at such a concentration, a larva would have eaten between 1.2 to $5 \mathrm{OBs}$. The lethal concentration observed for CpGV-R5 OBs in resistant insects is in the same range.

Accordingly, at low doses, most larvae that died from granulosis disease would have consumed only one or a few OBs. The highest probability for obtaining a mixed infection is when both viruses are present at the same frequency. For a larva eating $5 \mathrm{OBs}$ (the upper estimation for $\mathrm{LD}_{50}$ on susceptible insects) randomly selected from a mixed population containing 50\% CpGV-R5 and 50\% CpGV-M; the probability of "had eaten both CpGV-M and CpGV-R5" is 0.84 . In a population containing $90 \%$ CpGV-M and 10\% CpGV-R5, for the same doses, only 38\% of the insects would have eaten both virus genotypes. This probability increases when the number of OBs ingested increases. In our conditions, only when challenging hosts with a virus population containing 50\% CpGV-R5 and 50\% CpGV-M, almost all larvae will have consumed both virus genotypes (apart from insects treated with the lowest virus concentrations).

In addition, as in GVs, occlusion derived virions carry a single genome, and this helper effect for replication cannot occur unless a particular host cell is infected by at least two virions, one of which is a helper-genotype. Given these conditions, multiple infection of a midgut cell is probably a very rare event. Moreover, each infecting virus particle must be able to accomplish the whole cycle of infection, replication and cell-to-cell transmission within the infected insect. Accordingly, as the presence of CpGV-R5 in the host helps CpGV-M virions to infect, a possible explanation would involve a diffusible factor secreted by CPGV-R5-infected cells that renders non-infected cells permissive to CpGV-M infection. Alternatively, some cells could host a latent blocked infection of CPGV-M that becomes released if a CPGV-R5 superinfects.

Surprisingly, both virus genotypes were detected after replication of all experimental virus populations on RGV larvae, raising questions concerning the possible interactions between the viruses when infecting the larvae and the individual cells that should be explored further. 


\section{Conclusions}

The use of mixed genotype virus isolates as the basis for biological insecticides allows efficient pest control while preserving virus diversity and probably reducing the impact of selective pressures on the pest population that favors resistance development. This would likely reduce the speed or the probability of generation of insect populations showing resistance to these virus isolates. Combining this approach with co-evolution of virus populations with the natural pest populations they are targeting will likely prevent development of new cases of resistance, making the biological control of this insect sustainable.

Acknowledgments: This study received funding from the European Commission Seventh Framework Programme (FP7/2007-2013), under grant agreement FP7-265865. Benoit Graillot received an Agence Nationale de la Recherche Technologique doctoral scholarship. We thank T. Williams (Instituto de Ecologia (INECOL), Mexico) for constructive comments.

Author Contributions: Myriam Siegwart, Samantha Besse, Benoit Graillot and Miguel Lopez-Ferber conceived and designed the experiments. Benoit Graillot, Christine Blachere-Lopez and Sandrine Bayle performed the experiments. Samantha Besse provided the CpNPP colony and determined all the virus titers. Benoit Graillot, Christine Blachere-Lopez, Sandrine Bayle and Miguel Lopez-Ferber analysed the results. All authors contributed to writing.

Conflicts of Interest: The authors declare no conflict of interest.

\section{References}

1. ICTV Virus Taxonomy, 2013 Release, EC 45. Available online: http://www.ictvonline.org/ (accessed on 14 September 2015).

2. Tanada, Y. A granulosis virus of the codling moth, Carpocapsa pomonella (Linnaeus) (Olethreutidae, Lepidoptera). J. Insect Pathol. 1964, 6, 378-380.

3. Luque, T.; Finch, R.; Crook, N.; O'Reilly, D.R.; Winstanley, D. The complete sequence of the Cydia pomonella granulovirus genome. J. Gen. Virol. 2001, 82, 2531-2547. [CrossRef] [PubMed]

4. Lacey, L.A.; Thomson, D.; Vincent, C.; Arthurs, S.P. Codling moth granulovirus: A comprehensive review. Biocontrol Sci. Technol. 2008, 18, 639-663. [CrossRef]

5. Crook, N.E.; Spencer, R.A.; Payne, C.C.; Leisy, D.J. Variation in Cydia pomonella granulosis virus isolates and physical maps of the DNA from three variants. J. Gen. Virol. 1985, 66, 2423-2430. [CrossRef]

6. Fritsch, E.; Undorf-Span, K.; Kienle, J.; Zebitz, C.P.W.; Huber, J. Apfelwickler-Granulovirus: Erste Hinweise auf Unterschiede in der Empfindlichkeit lokaler Apfelwickler-Populationen. Nachricht. Deutsch. Pflanzenschutz. 2005, 57, 29-34.

7. Sauphanor, B.; Berling, M.; Toubon, J.F.; Reyes, M.; Delnatte, J.; Allemoz, P. Carpocapse des pommes: Cas de résistance au virus de la granulose en vergers biologiques. Phytoma Def. Veg. 2006, 590, $24-27$.

8. Schmitt, A.; Bisutti, I.L.; Ladurner, E.; Benuzzi, M.; Sauphanor, B.; Kienzle, J.; Zingg, D.; Undorf-Spahn, K.; Fritsch, E.; Huber, J.; et al. The occurrence and distribution of resistance of codling moth to Cydia pomonella granulovirus in Europe. J. Appl. Entomol. 2013, 137, 641-649. [CrossRef]

9. Asser-Kaiser, S.; Fritsch, E.; Undorf-Spahn, K.; Kienzle, J.; Eberle, K.E.; Gund, N.A.; Reineke, A.; Zebitz, C.P.W.; Heckel, D.G.; Huber, J.; et al. Rapid emergence of baculovirus resistance in codling moth due to dominant, sex-linked inheritance. Science 2007, 317, 1916-1918. [CrossRef] [PubMed]

10. Asser-Kaiser, S.; Radtke, P.; El-Salamouny, S.; Winstanley, D.; Jehle, J.A. Baculovirus resistance in codling moth Cydia pomonella L. caused by early block of virus replication. Virology 2011, 410, 360-367. [CrossRef] [PubMed]

11. Rezapanah, M.; Shojai-Estabragh, S.; Huber, J.; Jehle, J.A. Molecular characterization of new isolates of Cydia pomonella granulovirus from Iran. J. Pest. Sci. 2008, 81, 187-191. [CrossRef]

12. Eberle, K.E.; Asser-Kaiser, S.; Sayed, S.M. Overcoming the resistance of codling moth against conventional Cydia pomonella granulovirus (CpGV-M) by a new isolate CpGV-I12. J. Invertebr. Pathol. 2008, 98, $293-298$. [CrossRef] [PubMed] 
13. Berling, M.; Blachere-López, C.; Soubabere, O.; Lery, X.; Bonhomme, A.; Sauphanor, B.; López-Ferber, M. Cydia pomonella granulovirus genotypes overcome virus resistance in the codling moth and improve virus efficiency by selection against resistant hosts. Appl. Environ. Microbiol. 2009, 75, 925-930. [CrossRef] [PubMed]

14. Gebhardt, M.M.; Eberle, K.E.; Radtke, P.; Jehle, J.A. Baculovirus resistance in codling moth is virus isolate-dependent and the consequence of a mutation in viral gene pe38. PNAS 2014, 111, 15711-15716. [CrossRef] [PubMed]

15. Read, A.F.; Taylor, L.H. The ecology of genetically diverse infections. Science 2001, 292, 1099-1102. [CrossRef] [PubMed]

16. Mideo, N. Parasite adaptations to within-host competition. Trends Parasit. 2009, 25, 261-268. [CrossRef] [PubMed]

17. Muñoz, D.; Castillejo, J.I.; Caballero, P. Naturally occurring deletion mutants are parasitic genotypes in a wild-type nucleopolyhedrovirus population of Spodoptera exigua. Appl. Environ. Microbiol. 1998, 64, 4372-4377. [PubMed]

18. Hitchman, R.B.; Hodgson, D.J.; King, L.A.; Hails, R.S.; Cory, J.S.; Possee, R.D. Host mediated selection of pathogen genotypes as a mechanism for the maintenance of baculovirus diversity in the field. J. Invertebr. Pathol. 2007, 94, 153-162. [CrossRef] [PubMed]

19. Possee, R.D.; Rohrmann, G.F. Baculovirus Genome Organization and Evolution. In The Baculoviruses; Miller, L.K., Ed.; Plenum Press: New York, NY, USA, 1997; pp. 109-140.

20. Huber, J. Use of Baculoviruses in Pest Management Programs. In The Biology of Baculoviruses; Granados, R.R., Federici, B.A., Eds.; CRC Press: Boca Raton, FL, USA, 1986; Volume 2, pp. 182-202.

21. Hoy, M.A. Myths, models and mitigation of resistance to pesticides. Phil. Trans. R. Soc. B 1998, 353, 1787-1795. [CrossRef] [PubMed]

22. Briese, D.T.; Mende, H.A.; Grace, T.D.C.; Geier, P.W. Resistance to a nuclear polyhedrosis virus in the light-brown apple moth Epiphyas postvittana (Lepidoptera: Tortricidae). J. Invertebr. Pathol. 1980, 36, 211-215. [CrossRef]

23. Fuxa, J.R. Ecology of insect nucleopolyhedroviruses. Agric. Ecosyst. Environ. 2004, 103, 27-43. [CrossRef]

24. Lee, H.H.; Miller, L.K. Isolation of genetic variants of Autographa californica nuclear polyhedrosis virus. J. Virol. 1978, 3, 754-767.

25. Graham, R.I.; Tyne, W.I.; Possee, R.D.; Sait, S.M.; Hails, R.S. Genetically variable nucleopolyhedrovirueses isolated from spatially separated populations of the winter moth Operophtera brumata (Lepidoptera: Geometridae) in Orkney. J. Invertebr. Pathol. 2004, 87, 29-38. [CrossRef] [PubMed]

26. Simón, O.; Williams, T.; López-Ferber, M.; Caballero, P. Genetic structure of a Spodoptera frugiperda nucleopolyhedrovirus population: High prevalence of deletion genotypes. Appl. Environ. Microbiol. 2004, 70, 5579-5588. [CrossRef] [PubMed]

27. Eberle, K.E.; Sayed, S.; Rezapanah, M.; Shojai-Estabragh, S.; Jehle, J.A. Diversity and evolution of the Cydia pomonella granulovirus. J. Gen. Virol. 2009, 90, 662-671. [CrossRef] [PubMed]

28. Vickers, J.M.; Cory, J.S.; Entwistle, P.F. DNA characterization of eight geographic isolates of granulosis viruses from the potato tuber moth Phthorimaea operculella (Zeller) (Lepidoptera, Gelechiidae). J. Invertebr. Pathol. 1991, 57, 334-342. [CrossRef]

29. Bull, J.C.; Godfray, H.C.J.; O'Reilly, D.R. Persistance of an occlusion-negative recombinant nucleopolyhedrovirus in Trichoplusia $n i$ indicates high multiplicity of cellular infection. Appl. Environ. Microbiol. 2001, 67, 5204-5209. [CrossRef] [PubMed]

30. López-Ferber, M.; Simón, O.; Williams, T.; Caballero, P. Defective or effective? Mutualistic interactions between virus genotypes. Proc. R. Soc. B 2003, 270, 2249-2255. [CrossRef] [PubMed]

31. Clavijo, G.; Williams, T.; Simón, O.; Muñoz, D.; Cerutti, M.; López-Ferber, M.; Caballero, P. Mixtures of complete and pif1- and pif2-deficient genotypes are required for increased potency of an insect nucleopolyhedrovirus. J. Virol. 2009, 83, 5127-5136. [CrossRef] [PubMed]

32. Simón, O.; Williams, T.; López-Ferber, M.; Caballero, P. Functional importance of deletion mutant genotypes in an insect nucleopolyhedrovirus population. Appl. Environ. Microbiol. 2005, 71, 4254-4262. [CrossRef] [PubMed] 
33. Graillot, B.; Berling, M.; Blachere-López, C.; Siegwart, M.; Besse, S.; López-Ferber, M. Progressive adaptation of a CpGV isolate to codling moth populations resistant to CpGV-M. Viruses 2014, 6, 5135-5144. [CrossRef] [PubMed]

34. Graillot, B.; Berling, M.; Blachere-López, C.; Siegwart, M.; Besse, S.; López-Ferber, M. Correction: Progressive adaptation of a CpGV isolate to codling moth populations resistant to CpGV-M. Viruses 2015, 7, 6313-6315. [CrossRef]

35. Finney, J.R. Probit Analisis, 3rd ed.; Cambridge University Press: Cambridge, UK, 1971.

36. LeOra. POLO-PC SOFTWARE. A User'S Manual for Probit or Logit Analysis; LeOra Software: Berkeley, CA, USA, 1987.

37. Tanada, Y.; Hukuhara, T. Enhanced infection of a nuclear-polyhedrosis virus in larvae of the armyworm, Pseudaletia unipuncta, by a factor in the capsule of a granulosis virus. J. Invertebr. Pathol. 1971, 17, 116-126. [CrossRef]

38. Hashimoto, Y.; Corsaro, B.G.; Granados, R.R. Location and nucleotide sequence of the gene encoding the viral enhancing factor of the Trichoplusia ni granulosis virus. J. Gen. Virol. 1991, 72, 2645-2651. [CrossRef] [PubMed]

39. Peng, K.; van Lent, J.W.; Boeren, S.; Fang, M.; Theilmann, D.A.; Erlandson, M.A.; Vlak, J.M.; van Oers, M.M. Characterization of novel components of the baculovirus per os infectivity factor complex. J. Virol. 2012, 86, 4981-4988. [CrossRef] [PubMed]

40. Kikhno, I.; Gutiérrez, S.; Croizier, L.; Croizier, G.; López-Ferber, M. Characterization of pif, a gene required for the per os infectivity of Spodoptera littoralis nucleopolyhedrovirus. J. Gen. Virol. 2002, 83, 3013-3022. [CrossRef] [PubMed]

41. Clavijo, G.; Williams, T.; Muñoz, D.; Caballero, P.; López-Ferber, M. Mixed genotype transmission bodies and virions contribute to the maintenance of diversity in an insect virus. Proc. Roy. Soc. B 2010, 277, 943-951. [CrossRef] [PubMed]

(C) 2016 by the authors; licensee MDPI, Basel, Switzerland. This article is an open access article distributed under the terms and conditions of the Creative Commons Attribution (CC-BY) license (http://creativecommons.org/licenses/by/4.0/). 